\title{
STUDY OF THE EQUATORIAL ATLANTIC OCEAN MIXING LAYER USING A ONE-DIMENSIONAL TURBULENCE MODEL*
}

\author{
Udo Tersiano Skielka, ${ }^{1, * *}$, Jacyra Soares ${ }^{I}$ and Amauri Pereira de Oliveira ${ }^{l}$ \\ ${ }^{1}$ Universidade de São Paulo - Instituto de Astronomia, Geofísica e Ciências Atmosféricas \\ Departamento de Ciências Atmosférica \\ (Rua do Matão 1226, 05508-900 São Paulo, SP, Brasil) \\ **Corresponding author: udo@model.iag.usp.br
}

\begin{abstract}
A B S TR A C T
The General Ocean Turbulence Model (GOTM) is applied to the diagnostic turbulence field of the mixing layer (ML) over the equatorial region of the Atlantic Ocean. Two situations were investigated: rainy and dry seasons, defined, respectively, by the presence of the intertropical convergence zone and by its northward displacement. Simulations were carried out using data from a PIRATA buoy located on the equator at $23^{\circ} \mathrm{W}$ to compute surface turbulent fluxes and from the NASA/GEWEX Surface Radiation Budget Project to close the surface radiation balance. A data assimilation scheme was used as a surrogate for the physical effects not present in the onedimensional model. In the rainy season, results show that the ML is shallower due to the weaker surface stress and stronger stable stratification; the maximum ML depth reached during this season is around $15 \mathrm{~m}$, with an averaged diurnal variation of $7 \mathrm{~m}$ depth. In the dry season, the stronger surface stress and the enhanced surface heat balance components enable higher mechanical production of turbulent kinetic energy and, at night, the buoyancy acts also enhancing turbulence in the first meters of depth, characterizing a deeper ML, reaching around $60 \mathrm{~m}$ and presenting an average diurnal variation of $30 \mathrm{~m}$.
\end{abstract}

\section{RESUMO}

O modelo General Ocean Turbulence Model (GOTM) é aplicado para diagnosticar o campo de turbulência da camada de mistura oceânica $(\mathrm{CM})$ na região equatorial do Oceano Atlântico. Foram investigadas as estações chuvosa e seca, definidas, respectivamente, pela presença da zona de convergência intertropical e pelo seu deslocamento para norte. Simulações foram realizadas usando dados da bóia PIRATA $\left(0^{\circ}, 23^{\circ} \mathrm{W}\right)$ para o cálculo dos fluxos turbulentos de superfície e dados do Projeto NASA/GEWEX Surface Radiation Budget para "fechar" o balanço de radiação na superfície. Um esquema para assimilação de dados foi usado para considerar os mecanismos físicos não representados pelo modelo unidimensional. Para a estação chuvosa, os resultados mostraram uma CM rasa devido à menor tensão de cisalhamento na superfície e a estratificação estável da camada superior oceânica; a profundidade máxima alcançada é da ordem de $15 \mathrm{~m}$ com uma variação diurna média de $7 \mathrm{~m}$ de profundidade. Na segunda estação, a tensão de cisalhamento mais intensa e o aumento das trocas de calor em superfície geraram maior produção mecânica de energia cinética turbulenta e a noite o empuxo também favoreceu a formação de uma CM mais profunda, alcançando até $60 \mathrm{~m}$, e com variação diurna de $30 \mathrm{~m}$ em média.

Descriptors: Oceanic turbulence, General Ocean Turbulence Model, Equatorial Atlantic Ocean, Turbulent kinetic energy.

Descritores: Turbulência oceânica, Modelo geral de turbulência oceânica, Oceano Atlântico equatorial, Energia cinética turbulenta.

\section{INTRODUCTION}

The equatorial ocean is distinct from other oceanic regions due to its dynamic and thermodynamic particularities. Approaching the equatorial region, the geostrophic balance diminishes

(*) Paper presented at the Symposium on Oceanography, 4., 2008, São Paulo, IOUSP. in such way that the Ekman transport vanishes and the surface currents are driven by the easterlies. This causes a basin wide zonal inclination gradient that unbalances zonal momentum and generates a strong current to the east, right below the upper layer driven by the wind. This strong current is known as the equatorial undercurrent (EUC). The EUC responds to the wind strengthening and relaxation at the surface on a basin wide scale, which controls its depth and intensity (e.g. Philander, 1990). Over equatorial 
regions, the annual variations of the sea surface temperature (SST) are the dominant cycle and depend more on oceanic and air-sea interaction processes than on the annual cycle of the surface heat fluxes (Carton and Zhou, 1996; Yu et al., 2006 for the tropical Atlantic Ocean), prevailing variations of wind-induced vertical mixing, vertical and horizontal advection of heat (Weingartner and Weisberg, 1991a) and wind driven cooling due to evaporation, which is related to ocean-atmosphere feedback processes (e.g. Carton et al., 1996; Chang et al., 2000). All these processes are, direct or indirectly, related to the surface wind relaxation and strengthening that is determined, in great part, by the seasonal displacement of the intertropical convergence zone (ITCZ).

The ITCZ is located over regions of warmer waters, where intense atmospheric convection and, therefore, cloudiness and heavy precipitation exist (e.g. Hasthenrath 1991). When the ITCZ is located over a certain region, horizontal wind intensity weakens and cloudiness decreases the major components of the radiation surface balance. Despite the reduction in the incoming solar radiation at the surface, previous studies have identified the role of wind relaxation in promoting the increase in the SST as the result of two main factors: reduction of the wind-induced latent heat loss and the rise of the thermocline. This last factor is a non-intuitive mechanism, but as the thermocline approaches the surface it becomes easier to entrain cold water in the surface layer and thus decrease the SST. However, observational studies over the equatorial region have evidenced that sudden wind relaxation over the basin scale promotes a rapid cessation of the turbulent mixing, decoupling the mixing layer (ML) from the thermocline. Accordingly, observational studies of the equatorial Atlantic Ocean from the Seasonal Response of the Equatorial Atlantic program - SEQUAL (Weingartner and Weisberg 1991a,b; Weisberg and Tang 1987), indicate that the ML responds rapidly to the strengthening and weakening of the surface winds in the equatorial region. Weingartner and Weisberg (1991a), using measurements of temperature and velocity at the equator at $28^{\circ} \mathrm{W}$, showed that the uncoupling of the ML due to wind relaxation occurs in the middle of December and traps the net surface heat flux $\left(Q_{n}\right)$ in a thin upper layer, promoting during the following months a highly stable surface layer. This stable condition remains and is responsible for the progressive warming of the shallow ML until late April/early May when, with the strengthening of the wind, the upwelling movement and the mixing in the ocean are consequently turned on. From May on, the SST drops mainly due to the upwelling and zonal transport of cold water from the east. This drop in temperature is counterbalanced by transient eddies triggered by tropical instability waves, whose activity is more intense in June and July. In early August, the activity of the tropical instability waves diminishes and the cooling of the water due to advection ceases. In this period, the thermocline is deeper and attains a balance with the surface wind stress. From August to November, this state of equilibrium is maintained and the water temperature and salinity variations are smaller. The authors point out that during this period, one-dimensional mixing layer models might work accurately, since advection is less important and the surface heat fluxes seem to balance the turbulence mixing at the base of the ML.

More recently, Yu et al. (2006), using the dataset from OAFlux (Objectively Analyzed Air-Sea Fluxes, Yu et al., 2008), the ISCCP (International Satellite Cloud Climatology Project, Zhang et al., 2004) and the WOA (World Ocean Data, Levitus et al., 1994), estimated the correlation of the local variation of SST and the mixing layer depth $\left(h_{M L D}\right)$ with $Q_{n}$. They verified at the equator, westward from $20^{\circ} \mathrm{W}$, that the rise in the SST is characterized by the mechanism described by Weingartner and Weisberg (1991a), since a negative correlation between the variation of SST and the $h_{M L D}$ was indentified (the reduction of $h_{M L D}$ being related to an increase in SST, and vice-versa), while eastward of $20^{\circ} \mathrm{W}$, a strong positive correlation appears due to the known upwelling region off the African coast, where the depth of the thermocline responds directly to the strengthening of the easterlies. There, the easterlies transport the surface water away from the coast, promoting upwelling, which is related to the rise of the thermocline and the decrease in the SST.

The main goal of the present study is to investigate the extent of the turbulence of the equatorial Atlantic mixing layer using the General Ocean Turbulence Model (GOTM, Burchard et al. 1999). The version of GOTM used here is based on the $k-\varepsilon$ equations with the second-order turbulence closure scheme proposed by Canuto et al. (2001). This type of model has been tested and used in many studies of the upper ocean mixing layer (e.g. Burchard and Bolding, 2001; Bolding et al., 2002; Jefrey et al., 2008) and permits that the turbulence properties such as turbulent viscosity, tracer diffusivity, turbulent kinetic energy (TKE), dissipations rate of TKE, and others, be calculated.

The numerical simulations analyzed here will correspond to two periods: (i) February to April, when the ITCZ is over the region investigated hereafter called Season 1 - and (ii) August to October, when the ITCZ is displaced northward - called Season 2.

The data utilized in this study are described in section 2. The second-order turbulent closure model with $k-\varepsilon$ equations and the data assimilation are discussed in section 3 . To consider realistic equatorial 
features of the mean variables, oceanic in situ data from Prediction and Research Moored Array in the Tropical Atlantic (PIRATA) are assimilated to the GOTM. Section 4 presents the results and discussion and the conclusions are given in section 5 .

\section{Material And Methods}

Data and Region Investigated

The site chosen for this study is located at $\left(0^{\circ}, 23 \mathrm{~W}\right)$, where a PIRATA buoy (henceforward identified as B23W) is moored. This buoy is part of the PIRATA's backbone and has a long data series of the variables (Bourlès et al., 2008). It is the only buoy of the PIRATA array which has Acoustic Doppler Current Profile (ADCP) measurements, which is essential to account for the shear imposed by the EUC. Table 1 shows the different dataset used.

To compute the atmospheric turbulent fluxes at the surface - latent $\left(Q_{e}\right)$ and sensible $\left(Q_{h}\right)$ heat fluxes and the components of wind stress $\left(\tau_{x}\right.$ and $\left.\tau_{y}\right)$ the algorithm of the Coupled Ocean-Atmosphere Response Experiment (COARE) was used. It is based on aerodynamic bulk formulae and transfer coefficients obtained from the Monin-Obukhov Similarity Theory (Fairall et al., 2003) and it requires only information about air temperature and relative humidity, wind speed and SST (Table 1). The interface parameters were computed from $10 \mathrm{~min}$ averaged variables extracted from the PIRATA website. The corresponding turbulent fluxes were averaged hourly, resulting in hourly time series from 2000 to 2006, with some gaps. From these hourly series, hourly climatological series were computed. This climatological time series was used in the model simulations for Seasons 1 and 2.

Since the PIRATA array measures only the downward solar radiation (recently, PIRATA started measuring upward longwave radiation, but the data series of this variable is not as long as that of the downward shortwave radiation), data from the NASA Langley Research Center Atmospheric Sciences Data Center NASA/GEWEX Surface Radiation Budget Project (SRB) (http://gewex-srb.larc.nasa.gov) were used to close the surface radiation balance: the surface albedo, necessary to prescribe the shortwave surface balance $\left(I_{0}\right)$, and the longwave surface balance $\left(Q_{b}\right)$. The SRB estimated many radiative parameters globally with $1^{\circ} \times 1^{\circ}$ resolution, from July 1983 to June 2005, using satellite products, meteorological inputs from reanalysis and radiative transfer algorithms. Studies at the Air-Sea Interaction Research Lab-USP showed close agreement between the SRB dataset and PIRATA in situ measurements (Peres, 2007). In this study a time series compatible with that of the PIRATA time series was used, from 2000 to 2005 . Since the SRB has a time resolution of $3 \mathrm{~h}$, the radiative data series were linearly interpolated hourly.

Figure 1 shows the climatological hourly data series obtained from observed vertical profiles. Features similar to those described by Weingartner and Weisberg (1991a,b) may be observed in Figure 1. For temperature (Fig. 1a), one may observe higher values of SST and a more highly stratified water column in Season 1. From May onwards, the rapid decrease in temperature is related to the onset of the wind. In Season 2 a more vertically homogeneous temperature is evidenced. Figure $1 \mathrm{~b}$ shows a shallower position of the EUC, between 50 and $80 \mathrm{~m}$, for Season 1, whilst in Season 2 the EUC is located deeper, below $70 \mathrm{~m}$.

Table 1. Dataset used in the model run at location $\left(0^{\circ}, 23^{\circ} \mathrm{W}\right)$.

\begin{tabular}{lccc}
\hline \hline PIRATA & SRB-NASA & Specification on the model \\
\hline Meteorological & $\begin{array}{c}\text { Air temperature; } \\
\text { Sea surface temperature; } \\
\text { Relative humidity; } \\
\text { Wind components (u and v); } \\
\text { Downward shortwave. } \\
\text { Oemperature, salinity and } \\
\text { Oceanographic }\end{array}$ & $\begin{array}{c}\text { Upward shortwave; } \\
\text { Downward and upward } \\
\text { longwave. }\end{array}$ & $\begin{array}{c}\text { Upper boundary conditions: } \\
\text { Momentum and heat turbulent fluxes; } \\
\text { Surface radiation budget. }\end{array}$ \\
\hline
\end{tabular}



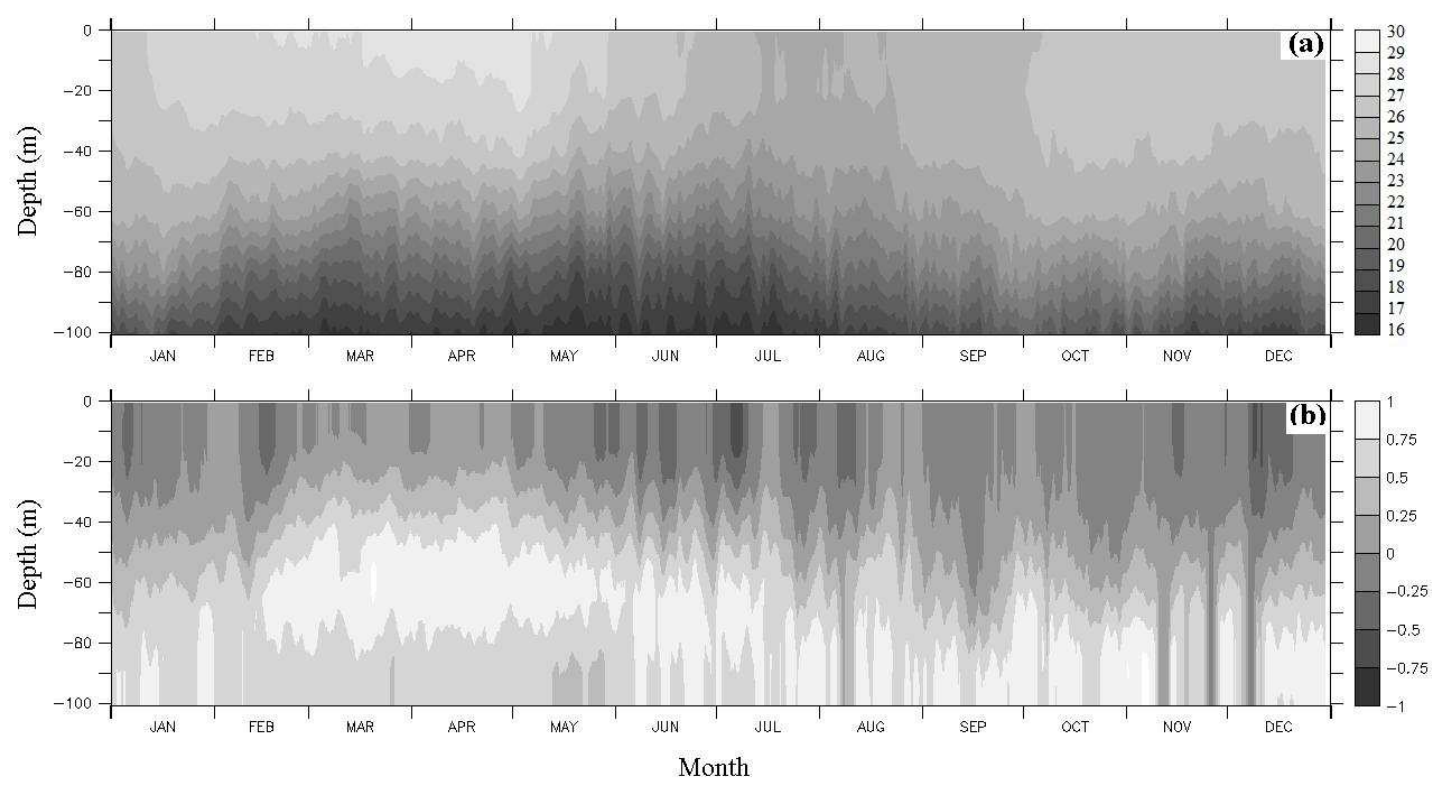

Fig. 1. Annual cycle of the vertical profiles of (a) temperature $\left({ }^{\circ} \mathrm{C}\right)$ and $(\mathrm{b})$ zonal velocity $\left(\mathrm{m} \mathrm{s}^{-1}\right)$. Data are hourly average values computed for the B23W dataset from 2000 to 2006, smoothed by a 5-day running mean.

Second-order Turbulent Closure with $k-\varepsilon$ Equations

In this study a second-order turbulent closure model is used with $k-\varepsilon$ equations implemented in the GOTM (Burchard et al. 1999). The second-order closure coefficients used are from Canuto et al. (2001) and according to Burchard and Bolding (2001) this closure is numerically stable, computationally cheap and showed greatest accuracy in simulating ML when the results are compared with idealized and real environment cases.

Second-order closure has been shown to achieve a good compromise in simulating turbulent processes in oceanic boundary layers in many environments, since it has low computational cost and is accurate in simulating the relevant mixing processes in high Reynolds number environments.

Generally speaking, to close the mean equation system it is necessary to estimate the covariance between the turbulent variables $\left(\overline{\mathrm{x}^{\prime} \mathrm{w}^{\prime}}\right)$, as described by Eq. 1:

$\overline{x^{\prime} w^{\prime}}=-v_{t} \partial_{z} X$

Where $v_{t}$ is turbulent viscosity and $\partial_{z} X$ the flow mean gradient.

The turbulent viscosity depends on the TKE, $k$, and its dissipation rate, $\varepsilon$, which are prognosticated using dynamic equations, and on so-called nondimensional stability functions (Burchard et al., 1999 and Burchard and Baumert, 1995). These stability functions contain all the information on the secondorder closure and depend basically on the semiempirical constants and the gradients of the mean flow: the shear frequency (Eq. 2) and the buoyancy frequency (Eq. 3).

$S=\left[\left(\partial_{z} U\right)^{2}+\left(\partial_{z} V\right)^{2}\right]^{1 / 2}$

$N=\left[-g \rho_{0}^{-1}\left(\partial_{z} \rho\right)\right]^{1 / 2}$

Where $(U, V)$ are the mean horizontal velocity components; $\partial_{z}$ is the vertical derivative; $\rho$ the mean ocean density, $\rho_{0}$ the reference density, and $g$ the acceleration due to gravity.

The TKE equation, given by Eq. 4, is composed of the following terms: Eq. 5 is the shear or the mechanical production which depends on the shear frequency and the turbulent viscosity $\left(v_{t}^{m}\right)$; Eq. 6 is the buoyancy production/consumption and depends on the buoyancy frequency and the temperature turbulent diffusivity $\left(v_{t}^{h}\right)$; Eq. 7 is the vertical diffusion, parameterized by the semi-empirical parameter called Schimidt number $\left(\sigma_{k}\right)$ and $v_{t}^{m}$; the viscous dissipation rate of TKE $(\varepsilon)$ is given by Eq. 8, which is a linear combination of the terms of Eq. 4 and the semiempirical parameters $c_{\varepsilon 1}, \quad c_{\varepsilon 2}, c_{\varepsilon 3}$ and a vertical diffusion term $\left(T_{\varepsilon}\right)$. Further details may be found in Burchard et al. (1999). 


$$
\begin{aligned}
& \partial_{t} k=P+B+T-\varepsilon \\
& P=v_{t}^{m} S^{2} \\
& B=v_{t}^{h} N^{2} \\
& T=v_{t}^{m} \sigma_{k}^{-1}\left(\partial_{z} k\right) \\
& \partial_{t} \varepsilon=\frac{\varepsilon}{k}\left(c_{\varepsilon 1} P+c_{\varepsilon 3} B+c_{\varepsilon 2} \varepsilon\right)-T_{\varepsilon}
\end{aligned}
$$

Numerically, the model has a staggered Cartesian vertical grid from the bottom, $z=-H$, to the free surface, $z=\zeta$, and uses a scheme centered in space and advanced in time to solve a diffusion equation. Further details may be seen in Burchard et al. (1999).

Data Assimilation and Simulation Details

An assimilation scheme was used in the mean equations in order to consider effects not represented by the one-dimensional model, such as advection, input of freshwater at surface and also the large-scale mechanisms. For example, the EUC, which is driven below the ML due to the basin-wide pressure gradient, can be given by the zonal current observations.

Expression 9 shows the assimilation term, considered in the numerical mean equations (momentum, heat and salt conservations) and it depends on the difference between the variable prognosticated by the model $(X)$ and that actually observed $\left(X_{o b s}\right)$ - which is small as the correction to the observations is performed at each time step - and after a prescribed period of assimilation $\left(T_{a s s i m}\right)$.

$\partial_{t} X \propto-T_{a s s i m}^{-1}\left(X-X_{o b s}\right)$

The vertical resolution of the observations may be considered coarse compared to the model resolution. Usually, the vertical resolution of PIRATA observations is $5 \mathrm{~m}$ for current velocity, $20 \mathrm{~m}$ for temperature and $40 \mathrm{~m}$ for salinity, while the model uses $1 \mathrm{~m}$ as vertical resolution. Therefore, an ideal assimilation period had to be determined so that the observational time series, linearly interpolated to the model grid, would not compromise the computation of the turbulent quantities. After testing the performance of different values, an ideal $T_{\text {assim }}$ of 1 day was found. As the mean variables are well represented in the numerical model, the turbulent quantities, obtained by the model, should also be correct.

The model uses no slip and no fluxes as bottom boundary condition. Therefore, the model's vertical domain was chosen so that the effect of the bottom would not influence the upper boundary layer simulation. The vertical domain considered for both simulations (Seasons 1 and 2) is from $\mathrm{z}=0 \mathrm{~m}$, at the surface, to $\mathrm{z}=-200 \mathrm{~m}$, in an equally spaced Cartesian grid of 1 meter. A time step of $60 \mathrm{~s}$ was used.

\section{Surface Boundary Conditions}

The upper boundary conditions for the model are specified in terms of the atmospheric surface fluxes of stress $\left(\tau_{\mathrm{x}}\right.$ and $\tau_{\mathrm{y}}$ ), given by Eq. 10 , and of the net heat flux, $Q_{n}$, described by Eq. 11, where $Q_{b}$ is the longwave surface balance, $Q_{e}$ is the latent heat flux, $Q_{h}$ the sensible heat flux and $I_{0}$ the shortwave surface balance. Here a positive net surface heat flux corresponds to the heat gained by the ocean.

$-\rho\left(\overline{u^{\prime} w^{\prime}}\right)_{0}=\tau_{x} \quad ; \quad-\rho\left(\overline{v^{\prime} w^{\prime}}\right)_{0}=\tau_{y}$

$Q_{n}=Q_{b}+Q_{e}+Q_{h}+I_{0}$

In all simulations it was assumed that the salt flux, at the surface, was zero.

Figure 2 shows the daily averaged values computed from the hourly series used as surface boundary conditions. In Figure $2 \mathrm{a}$ the difference between the two seasons in relation to the atmospheric forcing is evidenced: the relaxation of the surface stress in Season 1 - with the lower values from February to the end of April - and the period of intensified winds during Season 2 - from August to the end of October.

There is low variability of the air-sea exchange at the equator during the year (Figure $2 b$ ). One can observe greater variability of the surface shortwave balance $\left(I_{0}\right.$, open square) in Season 1 due to cloudiness. Despite the variability of $I_{0}$, the longwave surface balance ( $Q_{b}$, solid square), obtained from SRB, does not show great variability during the year, being slightly higher in Season 2. The latent heat flux $\left(Q_{e}\right.$, open circle) over the ocean depends mostly on the wind intensity, being higher during Season 2. The sensible heat flux ( $Q_{h}$, cross), is practically negligible, being one order of magnitude smaller than the other terms. The resultant net surface heat flux $\left(Q_{n}\right.$, star), given by Eq. 11, shows great variability throughout the year.

Table 2 shows the average values for the surface fluxes for both seasons. Season 2 presents a higher input of energy from solar radiation (difference of $28.9 \mathrm{~W} \mathrm{~m}^{-2}$ ), probably due to less cloud cover of the sky compared to Season 1. The main difference between the two seasons is in the cooling due to evaporation, represented by $Q_{e}$. In Season 1 , the reduction in the intensity of the wind diminishes the latent heat lost at the surface (difference of $29.2 \mathrm{~W}$ $\mathrm{m}^{-2}$ ), this being the principal contributor to the higher $Q_{n}$ in this season. 

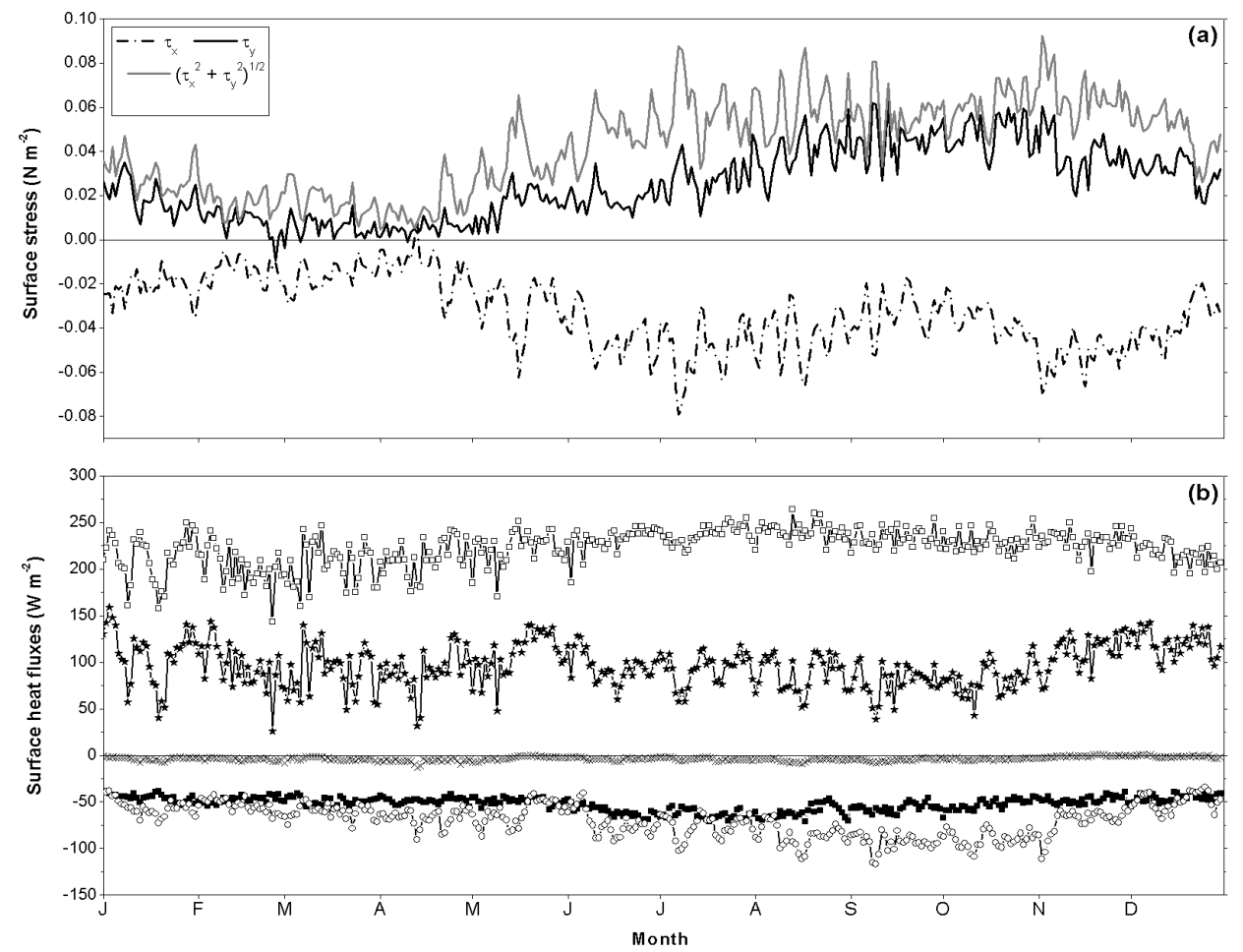

Fig. 2. Daily average values computed from the hourly time series. (a) Zonal stress (dashed-dotted line), meridional stress (black line) and the total stress (grey line) at surface, given by Eq. 10. (b) Components of the surface heat balance: $I_{0}$ (open square), $Q_{h}$ (cross), $Q_{b}$ (solid square), $Q_{e}$ (open circle) and $Q_{n}$ (star) given by Eq. 11.

Table 2: Mean values and standard deviations for the surface heat fluxes $\left(\mathrm{W} \mathrm{m}^{-2}\right)$ and stress horizontal components $\left(10^{-2} \mathrm{~N} \mathrm{~m}^{-2}\right)$ for each season. $I_{0}$ - shortwave surface balance; $Q_{h}$ - sensible heat flux; $Q_{e}-$ latent heat flux; $Q_{b}-$ longwave surface balance; $Q_{n}$ - net heat flux.

\begin{tabular}{cccccccc}
\hline \hline & $\tau_{x}$ & $\tau_{y}$ & $\boldsymbol{I}_{\boldsymbol{0}}$ & $\boldsymbol{Q}_{b}$ & $\boldsymbol{Q}_{\boldsymbol{e}}$ & $\boldsymbol{Q}_{\boldsymbol{h}}$ & $\boldsymbol{Q}_{\boldsymbol{n}}$ \\
\hline Season 1 & $-1.4(0.7)$ & 0.6 & $206.7(20.8)$ & $-48.4(3.5)$ & $-60.7(9.2)$ & $-5.1(2.0)$ & $92.5(23.3)$ \\
Season 2 & $-3.8(1.0)$ & $\begin{array}{c}(0.4) \\
4.4\end{array}$ & $234.6(11.0)$ & $-56.8(6.6)$ & $-89.9(10.1)$ & $-5.1(1.4)$ & $82.9(17.2)$ \\
\hline
\end{tabular}

\section{Results}

For the results presented here, the first 15 days of each simulation (Season 1 and Season 2), considered as a spin up period, have been neglected. So the results presented for Season 1 refer to the period from February 15 at $00 \mathrm{~h}$ to April 29 at $23 \mathrm{~h}$ and for Season 2 from August 15 at 00h to October 30 at $23 \mathrm{~h}$. Here the local time at $23^{\circ} \mathrm{W}$ is used. The heat gain at the ocean surface has been considered as having positive value.

\section{Simulation Results}

Figures 3 and 4 compare the mean field reproduced by the model with the observed data interpolated linearly in space and time. The choice of the $T_{\text {assim }}$ of 1 day attenuates the hourly variations and therefore the data assimilation scheme allows a smooth reproduction of the main features of each season. The diurnal cycle is well reproduced with the model performing as an optimized interpolator when data are missing at some depth, as for instance, interpolating the surface zonal current, which has a predominantly westward flow (Figs 3c,d and 4c,d).

Based on these reproduced mean fields, the turbulent properties were estimated by the turbulence closure of Canuto et al. (2001).

The mean features obtained in Figures 3 and 4 agree, for both seasons, with the studies of SEQUAL on this region. 

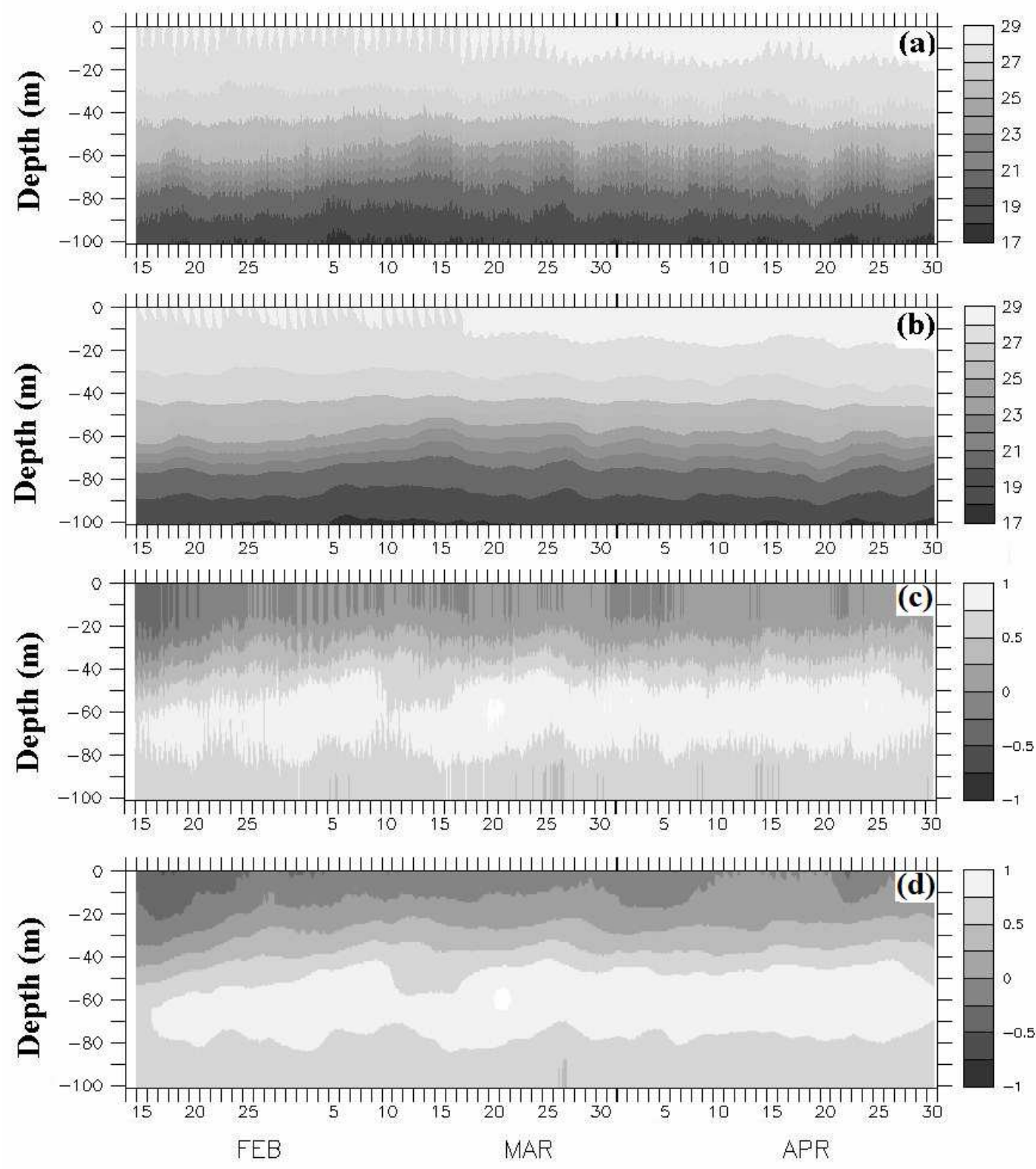

Time

Figure 3: Time variation of (a) observed temperature, (b) reproduced temperature $\left({ }^{\circ} \mathrm{C}\right)$, (c) observed zonal current and $(\mathrm{d})$ reproduced zonal current $\left(\mathrm{m} \mathrm{s}^{-1}\right)$. Season 1 . 

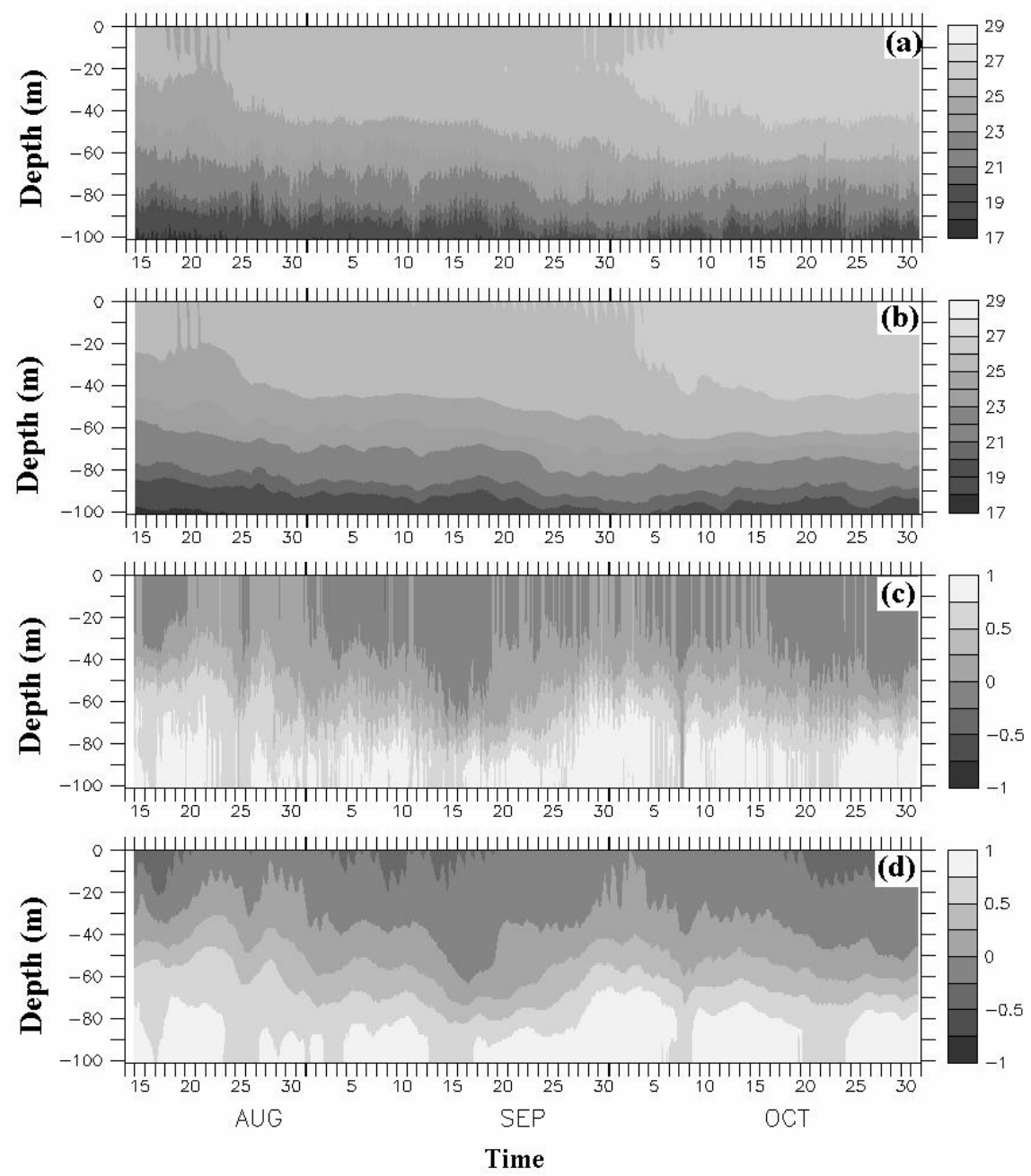

Fig. 4. Time variation of (a) observed temperature, (b) reproduced temperature $\left({ }^{0} \mathrm{C}\right)$, (c) observed zonal current and $(\mathrm{d})$ reproduced zonal current $\left(\mathrm{m} \mathrm{s}^{-1}\right)$. Season 2.

For the period of Season 1, the highest temperature values (Fig. 3a,b), with stable stratification in the upper layer are to be observed. The EUC is located near the surface, with its core varying from 50 to $80 \mathrm{~m}$ (Fig. 3c,d) during Season 1.

During Season 2 the vertical temperature field is more homogeneous (Fig. 4a,b) and the EUC is located deeper, with its core positioned below $70 \mathrm{~m}$. The westward momentum provided by the stronger winds is transferred down to greater depths (Fig. 4c,d).

Figure 5 shows the mean density field obtained from the $\mathrm{B} 23 \mathrm{~W}$ dataset together with the $h_{M L D}$ estimated by the model using a threshold value for the TKE of $10^{-5} \mathrm{~m}^{2} \mathrm{~s}^{-2}$. According to Burchard and Bolding (2001), below this value there is insufficient energy to mix the layer.
During Season 1 (Fig. 5a) the model estimates a shallow $h_{M L D}$ with a restricted diurnal variability, reaching a maximum depth around $15 \mathrm{~m}$ and mean diurnal amplitude around $7 \mathrm{~m}$. The closed density contour lines below the upper layer indicate the great vertical stratification occurring during this season.

During Season 2 (Fig. 5b) the ML is deeper, presenting greater diurnal variability with a mean value of $30 \mathrm{~m}$ but reaching $60 \mathrm{~m}$ in early October. The ocean during this season has less vertical stratification than during Season 1.

Monterey and Levitus (1997) and Montegut et al. (2004) estimated the climatological monthly values of $h_{M L D}$ for this region and obtained mean values shallower than $10 \mathrm{~m}$ for Season 1 and of less than $50 \mathrm{~m}$ for Season 2 . The estimated values of $h_{M L D}$, 
for both seasons, are, therefore, in agreement with the climatological dataset.

The modeled $h_{M L D}$ accompanies the narrowing of the density lines, which correspond to the deepening of the ML as observed, for example, in the period from February 26 to March 3 in Season 1 and from September $12-23$ in Season 2.

Figure 6 compares the two seasons using the accumulated heat content at the surface and in the water column at different depths. The accumulated heat was obtained at the surface by multiplying $Q_{n}$ by the time step simulation and adding up the values. The accumulated heat storage in the water column was estimated by computing the heat storage rate, given by Eq. 11, and proceeding as was done for $Q_{n}$, adding up the values cumulatively.

$\mathrm{Q}_{\mathrm{n}}=\rho \mathrm{c}_{\mathrm{p}} \mathrm{h}\left(\partial_{\mathrm{t}} \Theta+\overrightarrow{\mathrm{U}} \cdot \nabla \Theta\right)$

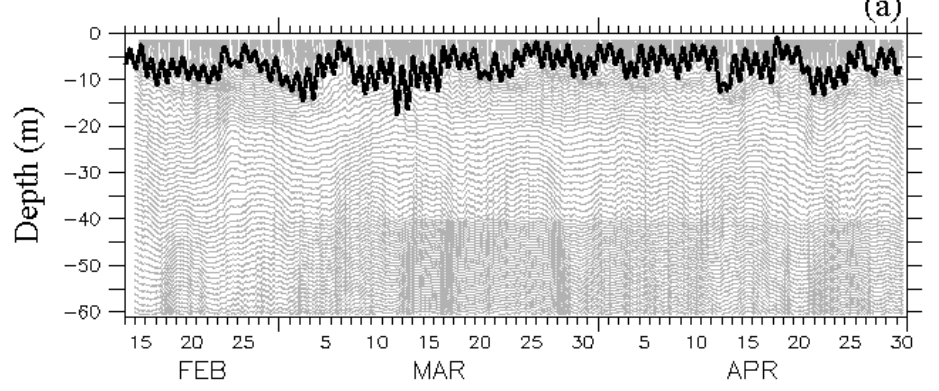

(b)

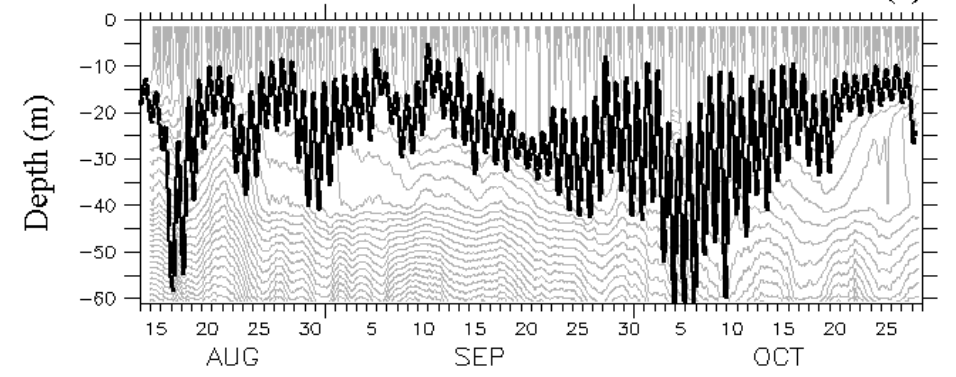

Time

Fig. 5. Density contours and the ML depth $\left(h_{M L D}\right)$ for (a) Season 1 and (b) Season 2. The contour interval is of $0.03 \mathrm{~kg} \mathrm{~m}^{-3}$. The thick black lines indicate the $h_{M L D}$ estimated using a TKE threshold of $10^{-5} \mathrm{~m}^{2} \mathrm{~s}^{-2}$.
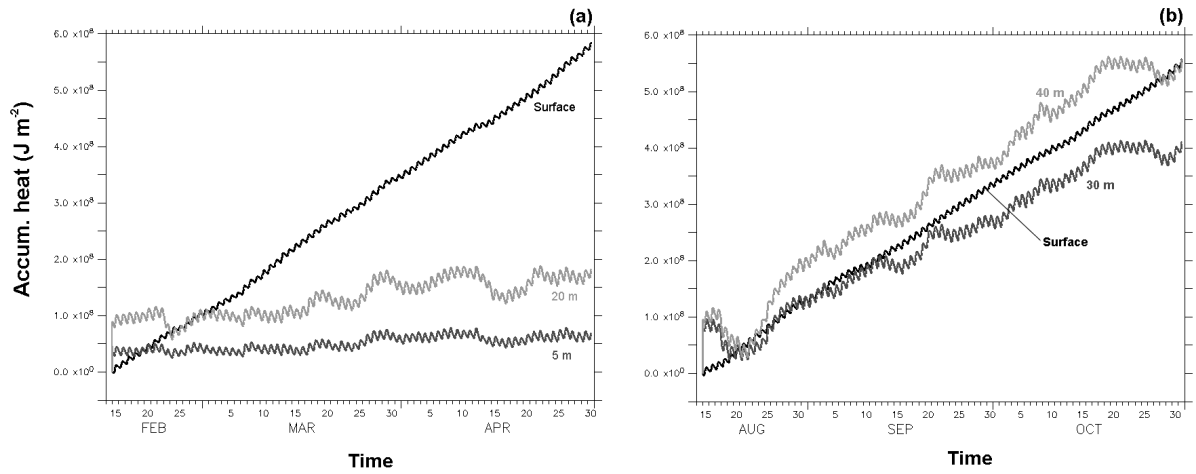

Fig. 6. Accumulated heat content. (a) Season 1 and (b) Season 2. For the surface heat content the computed net surface heat flux, $Q_{n}$, is used as a boundary condition. The others curves correspond to the heat storage rate integrated from the surface to the depth described in the figures -5 and $20 \mathrm{~m}$ for Season 1 and 30 and $40 \mathrm{~m}$ for Season 2. 
The water column heat budget, Eq. 12, was obtained using the heat and mass conservation equation for an incompressible fluid, as shown by Moisan and Niiler (1998), where $h$ is a depth at which the temperature is integrated from the surface; $\Theta$ is the temperature; $\vec{U}$ is the mean velocity vector; $c_{p}$ is the specific heat at constant pressure; $\partial_{\mathrm{t}}$ is time derivative. The first term on the right-hand side is the heat storage rate integrated into the water column and the second term is the change in heat storage due to temperature advection. Despite the use of a one-dimensional model in this study, in which the advection terms of the mean equations are explicitly neglected, the assimilation scheme used here is a way of accounting for some of these effects.

The heat content at the surface varies little from Season 1 to Season 2, being slightly higher in Season 1, as is also to be observed from the values of the mean surface heat flux components (Table 2). During Season 2, despite the higher input of energy from solar radiation due to the lesser cloud coverage, the greater wind velocity increases the latent heat lost at the surface (Fig. 2). The seasonal difference between the heat content at the surface, is, therefore, due to the smaller amount of latent heat lost in Season 1.

On the other hand, during Season 1 most of the heat reaching the surface is not distributed vertically in depth, or vertically mixed (Figure 6a.) Moreover, the heat accumulated between the surface and 5 and 20 meters is less than that accumulated at the surface. On the other hand, Figure $6 \mathrm{~b}$ shows that during Season 2 the heat accumulated at the surface is well distributed in depth with the heat accumulated in the integrated layers accompanying that accumulated at the surface. At $30 \mathrm{~m}$, the heat storage in this layer is in equilibrium with that at surface until around September 12, when the heat storage rate diminishes, corresponding to the deepening period of the ML observed in Figure 5b, when part of the heat is entrained to deeper layers.

According to Weingartner and Weisberg (1991a), the period of wind relaxation and presence of the ITCZ (Season 1) is characterized by downwelling movements of surface water down to around $75 \mathrm{~m}$ depth. This fact may be related to the slight variation in the accumulated heat storage in the 5 and $20 \mathrm{~m}$ layers, as shown in Figure 6a.

Waingartner and Weisberg (1999a) showed that after the boreal summer and through the fall (Season 2), advective events are weakened, since the zonal gradient of temperature diminishes and the upwelling and activity of the tropical instability waves cease. Weisberg and Tang (1987) observed that, in this period, the thermocline is locally in equilibrium with the zonal wind stress in such a way that surface heat and vertical diffusion is in balance, which keeps the
SST relatively constant. This fact is in agreement with the accumulated heat storage shown in Figure $6 b$.

Figure 7 shows the terms of the TKE equation (Eq. 4) normalized by the dissipation rate $(\varepsilon)$ of TKE as described in Eq. 13, for each season, taking a depth of $10 \mathrm{~m}$ for Season 1 and $30 \mathrm{~m}$ for Season 2.

$$
\frac{\mathrm{P}+\mathrm{B}+\mathrm{T}-\partial_{\mathrm{t}} \mathrm{k}}{\varepsilon}=1
$$

The local variation of TKE $\left(\partial_{t} k\right)$ and the vertical diffusion of TKE $(T)$ are much smaller than the other terms. In Season 1, it may be observed that TKE is generated only by shear production $(P)$ maintained by the surface wind stress in the shallow ML and that the buoyancy term $(B)$ acts consuming TKE (negative values).

In Season 2 (Figure 7b) it is shown that, during some periods, the buoyancy term may act generating turbulence at night at the same rate as it produces shear during the day. This occurs due to the greater surface cooling at night in this season, promoting a statically unstable surface layer (convection).

Figures $5 \mathrm{~b}$ and $7 \mathrm{~b}$ show that during September $15-25$, there is a deepening of the ML due to convection, as a result of the fact that during this period considerable buoyancy is produced at night. In the daytime, the buoyancy term acts to consume TKE, generated by the solar radiation, thus inducing a restratification of the ML. In Season 1 the stratified state of the upper layer prevents the production of turbulent buoyancy and the energy provided mechanically, by the winds, is not enough to promote deep mixing.

The turbulent Prandtl number $(P r)$ provides the ratio of the turbulent viscosity to temperature diffusivity (Eq. 14). This parameter may provide an insight into what processes dominate the turbulent mixing in the flow, since the turbulent viscosity depends mainly on shear, while temperature diffusivity depends on thermal and then buoyancy effects. Therefore, regions where $P r>1$ signifies a predominance of the mechanical production of TKE (Eq. 5) and where $P r<1$, a predominance of the buoyancy production of TKE (Eq. 6).

$\operatorname{Pr}=v_{t}^{m} / v_{t}^{h}$

Figure 8 compares the vertical profile of the Prandtl number $(\mathrm{Pr})$ for each season averaged at different hours. In Season 1 after $18 \mathrm{~h}$ (Fig. 8) the $\mathrm{Pr}$ diminishes at the surface and then, at night (Fig. 8a), the turbulent diffusivity of temperature $\left(v_{t}^{h}\right)$ is dominant at the first $5 \mathrm{~m}$ depth. This fact shows the influence of the nocturnal turbulent cooling that, despite the low values, is responsible for a deepening of the ML at night. The turbulent viscosity $\left(v_{t}^{m}\right)$ dominates rapidly at depths greater than around $20 \mathrm{~m}$. 
Below this depth, both coefficients are of the same order. During daytime (Figure 8b), the turbulent viscosity is dominant in the ML $(P r>1)$. A step-like change is observed in the Prandtl number at around 40 $m$ depth with values greater than one, both during night (Fig. 8a) and the day (Fig. 8b), probably associated with the increase in the shear caused by the presence of the EUC near this depth. According to Figure 3, the core of the EUC varies, during Season 1, from 50 to $80 \mathrm{~m}$.

The $v_{t}^{h}$ is dominant over a great part of the ML at night during Season 2 (Fig. 8c), characterizing a period of convective turbulence production. From $18 \mathrm{~h}$ (Figure 8d) to $06 \mathrm{~h}$ (Fig. 8c) a progressive increase of $v_{t}^{h}$ over $v_{t}^{m}$ is verified, the former being comparatively greater around $15 \mathrm{~m}$, from 03 to $06 \mathrm{~h}$. Below this depth, turbulent viscosity dominates as far as the region of EUC influence (eastward flow, from around $30 \mathrm{~m}$ deep, Fig. 4b). During daytime the temperature turbulent viscosity dominates. From $09 \mathrm{~h}$ to $12 \mathrm{~h}$ there is an increase in the $v_{t}^{m}$ and a reduction of the $v_{t}^{h}$, which can be related to an increase in the shear production (Fig. 7b). After $12 \mathrm{~h}$ the $v_{t}^{m}$ values decrease.
Fig. 7. Terms of the TKE equation (Eq. 4) normalized by the TKE dissipation rate, $\varepsilon$, for (a) Season 1 , average values for the first $10 \mathrm{~m}$ depth and (b) Season 2 at the first $30 \mathrm{~m}$ depth. Hourly values were averaged in time using a $6 \mathrm{~h}$ running mean.
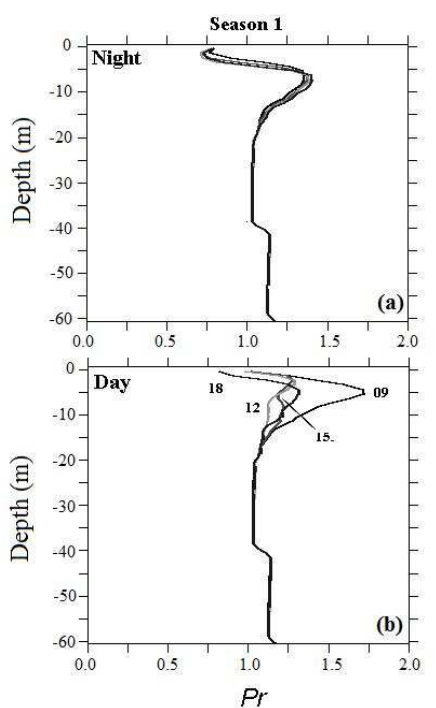
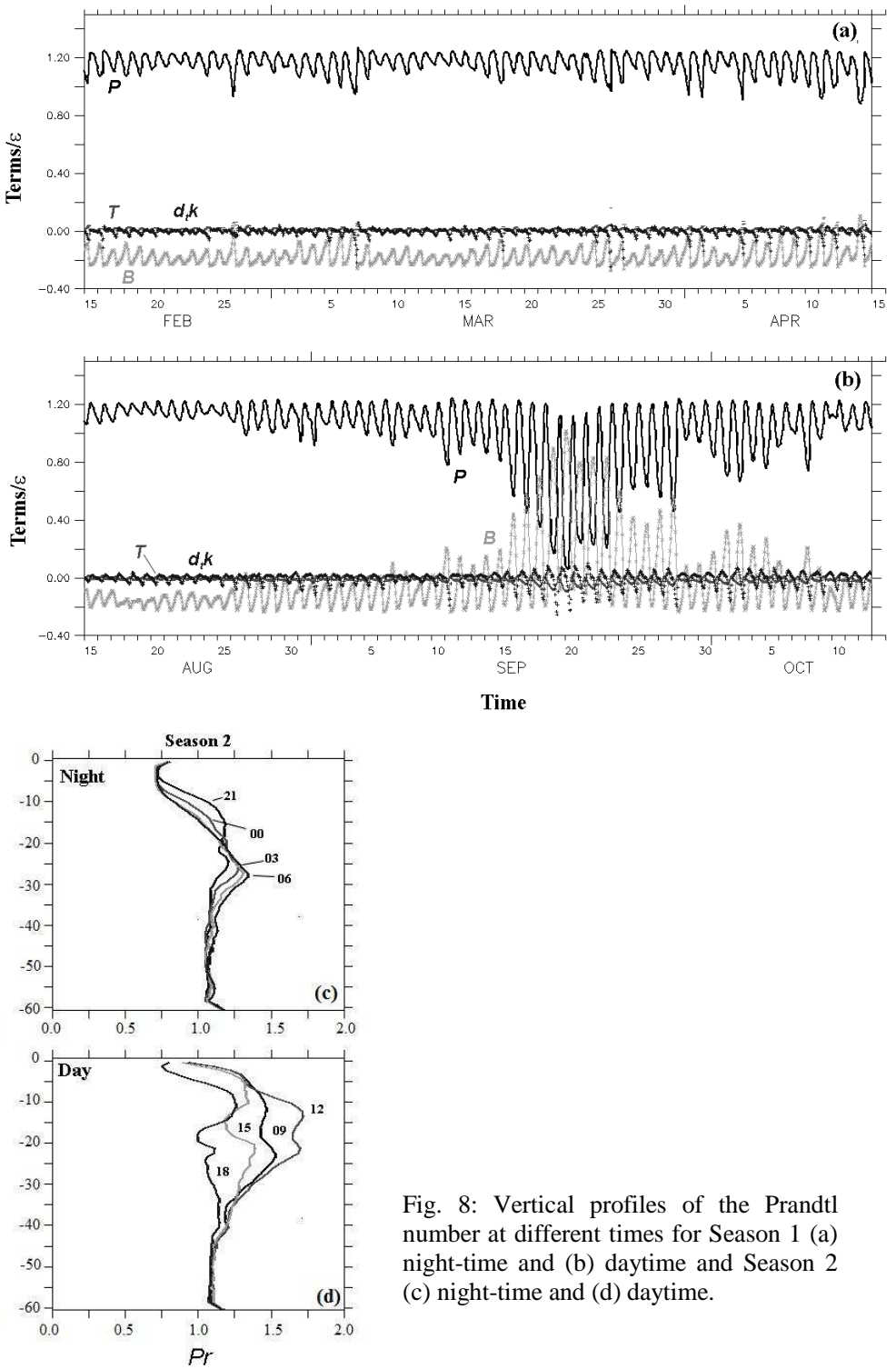

Fig. 8: Vertical profiles of the Prandtl number at different times for Season 1 (a) night-time and (b) daytime and Season 2 (c) night-time and (d) daytime. 


\section{DisCUSSION}

In this study the second-order turbulent closure of Canuto et al. (2001) using the $k-\varepsilon$ equations version of the General Ocean Turbulence Model (GOTM, Burchard et al., 1999) was applied over the equatorial Atlantic region to investigate the main features of the mixing layer of two well defined seasons in respect of the atmospheric forcing and the state of the upper ocean. The former occurs in the presence of the intertropical convergence zone identified as Season 1 - and the latter when the ITCZ is displaced northwards - identified as Season 2.

To compute the surface flux boundary conditions, the PIRATA dataset from the buoy located at $0^{\circ}$ lat., $23^{\circ} \mathrm{W}$ was used, using the algorithm of the Coupled Ocean-Atmosphere Response Experiment (Fairall et al., 2003). The PIRATA dataset was also used in the procedure of data assimilation during the numerical simulation of the water column's mean properties. Complementarily, the radiation dataset from NASA/GEWEX Surface Radiation Budget Project was used to close the surface radiation balance.

The surface fluxes presented only a small annual cycle despite the variability of the sea surface temperature occurring on this time scale. The slightly higher net surface heat was found during Season 1 due mainly to the lesser wind-induced latent heat lost.

The assimilation scheme used in this project reproduced the main features of the equatorial region faithfully, permitting a realistic representation of the turbulent properties and therefore allowing a comparison between the ML in the two seasons.

The estimated ML depth values are in agreement with the climatological estimate of Monterey and Levitus (1997) and Montegut el al. (2004). In Season 1, the maximum depth reached by the simulated ML was $15 \mathrm{~m}$, showing an averaged diurnal variation of $7 \mathrm{~m}$, while in Season 2, the ML depth reached approximately $60 \mathrm{~m}$ with an averaged diurnal variability of about $30 \mathrm{~m}$.

The analysis of the heat accumulated at the surface, obtained from the computed surface heat fluxes, and of the accumulated heat at different water column depths, obtained from the assimilated temperature vertical profile, showed the differences in the ML heat content in each season, as previously described by the observational work of Weisberg and Weingartner $(1999 a, b)$. The results showed that the ML heat accumulated during Season 1 is not in equilibrium with the surface net heat probably due to the temperature advection during this period, while in Season 2 a certain balance was verified (Figure 6).

The simulations indicated that the production of turbulent kinetic energy in the ML varies seasonally over the Tropical Atlantic. In Season 1 , the low wind intensity at the surface provides a small mechanical production of TKE. Besides, the highly stable stratification of the upper layer acts in such a way as to consume significant fractions of the TKE in the ML. Thus both effects prevent the growth of the ML during Season 1. On the other hand, the intensification of the wind velocity in Season 2 increases the mechanical production of TKE in the ML. Thermal convection induced by nocturnal surface cooling contributes to an increase in the TKE, promoting a deepening of the ML during Season 2.

Analyses of the Prandtl number at different times during each season showed that in Season 2, during night-time, the estimated temperature turbulent diffusivity is more important at the first $15 \mathrm{~m}$ depth than the turbulent viscosity, suggesting the existence of a convective regime of the nocturnal ML, probably caused by the increase in the surface longwave net lost. The convection observed at night and the restratification and suppression of TKE by the buoyancy term appears to be responsible for the higher amplitude of the diurnal variation of the depth of the ML during this season.

\section{ACKNOWLEDGEMENTS}

This work was financed by $\mathrm{CNPq}$ and Fapesp.

\section{REFERENCES}

BOLDING, K.; BURCHARD, H.; POHLMANN, T.; STIPS, A. Turbulent mixing in the Northern North Sea: a numerical model study. Cont. Shelf Res., v. 22, 2002. p. 2707-2724.

BOURLĖS, B.; MCPAHADEN, M. J.; HERNANDES, F.; NOBRE, P.; CAMPOS, E.; YU, L.; PLANTON, S.; BUSALACCHI, A., MOURA, A. D.; SERVAIN, J.; TROTTE, J. The PIRATA Program. History, accomplishments, and future directions. Bull. Amer. Meteor. Soc., 2008. p. 1111-1125, DOI:10.1175/2008BAMS2462.1.

BURCHARD, H.; BAUMERT, H. On the performance of a mixed-layer model based on the k-epsilon turbulence closure. J. Geophys. Res., v. 100, 1995. p. 8523-8540.

BURCHARD, H.; BOLDING, K. Comparative analysis of four second-moment turbulence closure models for the oceanic mixed layer. J. Phys. Oceanogr., v. 31, 2001. p. 1943-1968.

BURCHARD, H.; BOLDING, K.; VILLARREAL, M. GOTM - a general ocean turbulence model. Theory, applications and test cases. Tech.Rep. EUR 18745 EN, European Commission.

CANUTO, V. M.; HOWARD, A.; CHENG, Y.; DUBOVIKOV, M. S. Ocean turbulence. Part I: One point closure model, momentum and heat vertical diffusivities. J. Phys. Oceanogr., v. 31 (6), 2001. p. 1413-1426.

CARTON, J. A.; CAO X.; GIESE, B. S.; DA SILVA, A. M. Decadal and interannual SST variability in the tropical Atlantic. J. Phys. Oceanogr., v. 26, 1996. p. 1165-1175. 
CARTON, J. A.; ZHOU, Z. Annual cycle of sea surface temperature in the tropical Atlantic Ocean. J. Geophy. Res., v. 102, 1997. p. 27813-27824.

CHANG, P.; SARAVANAN, L.; JI, L.; HEGERL, G.C. The effect of local sea surface temperatures on atmospheric circulation over the tropical Atlantic sector. J. Climate, v. 13, 2000. p. 2195-2216.

DE BOYER MONTÉGUTE C.; MADEC, G.; FISHER, A. S.; LASAR, A.; IUDICONE, D. Mixed layer depth over the global ocean: an examination of profile data and a profile-based climatology. J. Geophys. Res., v. 109, 2004. DOI:10.1029/2004JC002378.

FAIRALL, C. W.; BRADLEY, E. F.; HARE, J. E.; GRACHEV, A. A.; EDSON, J. B. Bulk Parameterization of Air-Sea Fluxes: Updates and Verification for the COARE Algorithm. J. of Climate, v. 16, 2003. p. 571591.

HASTENRATH, S. Climate Dynamics of the Tropics. Kluwer Academic, 1991. 488p

JEFREY, C. D.; ROBINSON, I. S.; WOOLF, D. K.; DONLON, C. J. The response to phase-dependent wind stress and cloud fraction of the diurnal cycle of SST and air-sea CO2 exchange. Ocean Modelling. v. 23, 2008. p. $33-48$.

LEVITUS, S.; BOYER, T. P. Temperature. World Ocean Atlas 1994. NOAA Atlas NESDIS 4. v. 4, 1994. 117p.

MOISAN, J.; NIILER, P. The seasonal heat budget of the North Pacific: net heat fluxes and heat storage rates (1950-90). J. Phys. Oceanogr. v. 28, 1998. p. 401-421.

MONTEREY, G.; LEVITUS, S. Seasonal Variability of Mixed Layer Depth for the World Ocean. NOAA Atlas NESDIS 14, Natl. Oceanic and Atmos. Admin., Silver Spring, Md. 5 p.

PERES, J. R. 2008. Estudo do balanço de radiação sobre o oceano Atlântico Tropical na região do Arquipélago de São Pedro e São Paulo. Relatório Final de Iniciação Científica. Instituto de Astronomia, Geofísica e Ciências Atmosféricas. Universidade de São Paulo. 2008. 35 p. http://www.iag.usp.br/meteo/labmicro/publicacoes/relato rios_tecnicos/Jean_2008_Estudo_do_balanco_de_radiac ao_sobre_o_oceano_Atlantico_tropical_na_regiao_do_A SPSP.pdf
PHILANDER, S. G. El Niño, La Niña, and Southern Oscillation. Academic Press, Londres, 289. 1990. 289 p. WEINGARTNER, T. J.; WEISBERG, R. H. On the annual cycle of equatorial upwelling in the central Atlantic Ocean. J. Phys. Oceanogr. v. 21, 1991a. p. 68-82.

WEINGARTNER, T. J.; WEISBERG, R. H. A description of the annual cycle in the sea surface temperature and upper ocean heat in the equatorial Atlantic. J. Phys. Oceanogr. v. 21, 1991b. p. 82-96.

WEISBERG, T. J.; TANG, T. Y. Further studies on the response of the equatorial thermocline in the Atlantic Ocean to the seasonal varying trade winds. J. Phys. Oceanogr. v. 92, 1987. p. 3709-3727.

YU, L.; XIANGZE, X.; WELLER, R. A. Role of net surface heat fluxes in seasonal variations of sea surface temperature in the tropical Atlantic Ocean. J. Climate. v. 19, 2006. p. 6153-6169.

YU, L.; XIANGZE, X.; WELlER, R. A. Multidecade Global Flux Datasets from the Objectively Analyzed Air-sea Fluxes (OAFlux) Project: Latent and Sensible Heat Fluxes, Ocean Evaporation, and Related Surface Meteorological Variables. Woods Hole Oceanographic Institution. OAFlux Project Technical Report, 2008. 64p.

ZHANG, Y. C.; ROSSOW, W. B.; LACIS, A. A.; OINAS, V.; MISHCHENKO, M. I. Calculation of radiative fluxes from the surface to top of atmosphere based on ISCCP and other global data sets: refinements of the radiative transfer model and input data. J. Geophys. Res. v. 109, D19105, 2004. DOI: 10.1029/2003JD004457.

(Manuscript received 02 March 2009; revised 25 November 2009; accepted 02 March 2010) 